\title{
Imágenes, juegos, rituales y espacios. Las Interacciones socioculturales entre elites y sectores populares durante la entreguerras. La incultura en Rosario (Argentina)
}

Diego P. ROLDÁN ${ }^{\circ}$

\begin{abstract}
Resumen: Este artículo aborda las formas de presentación, interacción y conflicto desplegadas en el espacio urbano de Rosario (Argentina) entre los sectores populares y las elites durante el período de entreguerras. Los comportamientos analizados fueron tipificados por las elites como manifestaciones de incultura. El objetivo es estudiar este conjunto de prácticas intentando desexotizarlas a partir de una lectura hermenéutica y semiótica de sus operatorias, protocolos y relaciones socioculturales. Se mostrará cómo lo que para las elites era un conjunto de prácticas desarticuladas y sin sentido, constituía un complejo entramado de tácticas y estrategias de codificación y decodificación de la identidad social. Juegos sociales producidos en el marco de procesos de interacción dinámica basados en relaciones sociales y de poder asimétricas. La reconstrucción de estos fragmentos de las interacciones sociales del pasado pretende desentrañar los significados y operatorias de la construcción de identidades, juegos, rituales y espacios sociales.
\end{abstract}

Palabras clave: Prácticas; Cultura; Relaciones sociales; Interacción; Espacio.

- Dr. en Humanidades y Artes (Historia). Profesor de Enseñanza Media y Superior en Historia - Escuela de Historia - EH - Facultad de Humanidades y Artes - FhyA - Universidad Nacional de Rosario UNR - Rosário - Argentina. Jefe de Trabajos Prácticos de la Cátedra de Espacio y Sociedad en la Facultad de Humanidades y Artes de la Universidad Nacional de Rosario. E-mail: diegrol@hotmail.com

HISTÓRIA, São Paulo, 28 (2): 2009 


\section{Introducción}

Quien al estudiar la cultura de los sectores populares recorra la documentación oficial o periodística de la entreguerra se topará en reiteradas ocasiones con una palabra que posiblemente le resulte extraña: incultura. ${ }^{1}$ Esta aparición podrá ser considerada como un hecho marginal y pasar inadvertida, quedando fuera del campo analítico, fuera de la construcción de la problemática y también del objeto. De hecho así ha ocurrido en el pasado, a excepción quizá de los trabajos dedicados a las celebraciones del carnaval, algunos estudios tempranos sobre las relaciones elites sectores populares y el análisis de la sociabilidad en los cafés. ${ }^{2}$ La mayor parte de la producción historiográfica argentina en torno a los sectores populares se ha enfocado sobre ámbitos regulares y normativos en los que se producía y reproducía su cultura. ${ }^{3}$ En cierta medida, este enfoque ha transformado a los encuentros sociales que en la época fueron clasificados como incultura por los sectores letrados en un punto ciego del análisis.

Por el contrario, si el interés del investigador está colocado en los márgenes, en la construcción de un espacio-tiempo no vinculado al trabajo, las instituciones o a las actividades regulares y en los conflictos del campo cultural configurado a partir de la relación elites-sectores populares quizá la entidad de esa palabra extraña (incultura) comience a crecer. En parte este último ha sido mi caso y, también, parcialmente este artículo es el testimonio de la deriva hacia ese interés. ${ }^{4}$

El presente estudio abordará un entramado de formas de presentación, interacción y conflicto desplegadas en espacios públicos urbanos por los sectores populares en sus relaciones cortas (cara a cara) con las elites de la ciudad de Rosario (Argentina), durante el período que se extiende entre 1915 y 1940. La prensa de la ciudad caracterizó a estos comportamientos de los sectores populares como manifestaciones de incultura, en tanto ajenas a toda racionalidad (ratio). El artículo pretende estudiar este conjunto de prácticas intentando desexotizar las costumbres populares a 
IMÁGENES, JUEGOS, RITUALES Y ESPACIOS...

partir de una lectura hermenéutica y semiótica de sus operatorias, protocolos y relaciones. Así, se mostrará cómo lo que para la elite y la presa constituía un conjunto de prácticas desarticuladas y sin sentido, formaba un complejo entramado de tácticas y estrategias de codificación y decodificación de la identidad social, en el marco de procesos de interacción dinámicos, producidos, a su vez, en un espacio de relaciones sociales y de poder asimétricas. El foco se colocará en los distintos escenarios disponibles para la teatralización de las artes de hacer de la cultura popular. Las calles y los espacios públicos, plazas, paseos, los transportes populares (tranvías y ómnibus). Se pretende otorgar un marco de comprensión a la denominada incultura en tanto ritual de afirmación de la cultura juvenil en general y de la cultura de los sectores populares en particular y explorar sus componentes en términos de resistencia simbólica frente a los imperativos de la cultura dominante. De este modo, las interacciones dinámicas y fragmentarias se constituyen en las ventanas para desentrañar los significados y las operatorias de la cultura popular en un medio urbano específico.

\section{La incultura como producción social e histórica}

Ante todo, intentaré aproximarme y aproximar al lector a la aparición de la palabra incultura asociada con cierto campo de prácticas. Incultura es un significante que deja un sabor de lectura desconcertante, pero cuyo uso era frecuente durante la entreguerra. Actualmente, los usos sociales de la voz incultura son escasos, cuando no inexistentes. Sin embargo, el conjunto de fenómenos que la palabra delimitaba siguen constituyendo materia de preocupación social, su campo semántico estimula la imaginación social de los defensores y estudiosos del orden. Su relevo fue operado por términos procedentes de una sociología con base biológica, como el estructural funcionalismo, que utilizó con un sentido análogo voces como inadaptación o anomia comportamental. ${ }^{5}$ 
Además, el vocablo incultura posee vínculos con otros significantes que tipifican aquello que para la "buena sociedad" no es capaz de adoptar más que los nombres de "inmoral", "indecoroso", "deshonesto", "obsceno", "indecente", etc. Este conjunto de palabras fue aglutinado, durante la entreguerra, bajo la amplia e indefinida sombra que proyectaba la voz incultura. Desandar ese camino de derivaciones, hibridaciones, solapamientos y préstamos es un objetivo que escapa a este trabajo. Estas líneas no pretenden concentrarse en las transformaciones del vocabulario, antes quieren emprender el camino inverso: partir de las palabras para conducir una exploración hacia el entramado de las relaciones sociales.

Incultura fue, entonces, una palabra socialmente construida y difundida en los medios escritos de la ciudad de Rosario de la primera mitad del siglo XX. ${ }^{6}$ Ante todo, su formulación delimitaba un conjunto de prácticas a las que se pretendía adherir una valoración negativa. Cultura e incultura se presentaban en el léxico de la época como polos antitéticos que definían un campo de prácticas moralmente connotado. El primero (cultura) regulado, ordenado, sistemático y valioso, el segundo (incultura) espontáneo, caótico, falto de sentido y despreciable. En el período bajo estudio, la palabra cultura distinguía las actividades sistemáticas, reguladas y ordenadas de aquellas que carecían de estos atributos. El sentido de la palabra cultura era bastante amplio, sus restricciones fueron menos rígidas que las pautadas por la exclusividad de la alta cultura. No obstante, este significante jamás perdió de vista el carácter regular de las actividades a las que designaba, o bien la estima socialmente reconocida a las mismas. ${ }^{7}$

En la tríada definida por Charles S. Peirce (significadosignificante-contexto) la voz incultura enmarcó a las prácticas que eran representadas como formas irracionales o inexplicables de la acción humana. ${ }^{8} \mathrm{Al}$ mismo tiempo, performativamente esta definición aspiraba a propulsar una política de erradicación a largo plazo de las mismas, una victoria de la cultura asociada al progreso de los modales, la urbanidad y los valores aceptados. ${ }^{9}$ Desde el punto de vista de la cultura, la incultura era lo 
IMÁGENES, JUEGOS, RITUALES Y ESPACIOS...

irracional, lo inexplicable, aquello que no se podía pensar ni comprender y que sólo era pasible de difamación. Estas operaciones de atribución de sentido y producción de la diferencia se llevaban a cabo con arreglo a las supuestas barreras culturales que separaban a las elites de los sectores populares y, especialmente, a las invisibles tramas del poder y la dominación. ${ }^{10}$

En el plano lógico formal, la incultura constituía una tautología o un concepto autoevidente, puesto que la explicitación de sus contenidos se reducía a la práctica de su enunciación. Su potencia era resguardada por la homogeneidad identitaria del colectivo capaz de enunciarla y el contenido sobreentendido (implícito) que comportaba para sus miembros. Así, la lógica de la incultura estaba precedida por el principio de explicitación alojado en la propia reproducción de un ciclo continuo e idéntico a sí mismo, un movimiento de reforzamiento simbólico. La incultura implicaba y se explicaba por la ausencia de cultura. Ese razonamiento polarizado se profundizaba y ganaba fuerza con cada repetición, dejando fuera del alcance del discurso el secreto de su construcción. Las fórmulas retóricas, como las que entornaban a la incultura, aspiraban y aspiran a dotar de un estatuto explicativo a meras clasificaciones descriptivas. Necesariamente obtienen su potencia de la repetición y la substancialización que operan sobre los significados que pretenden englobar y modelar. Estos dos procesos (repetición y substancialización) se interconectan y retroalimentan a través de la fijación y la reproducción referida al objeto o sujeto al que aplican sus consecuencias retóricas, que aspiran convertirse en consecuencias (atribuciones de sentido) culturales y sociales. En el caso bajo estudio, los efectos de esta función también fueron valorativos. La incultura establecía una ausencia, una carencia, la falta de disciplina, de control, urbanidad y civilización indispensables para vivir en comunidad. Los modales y las formas que el ethos dominante (o que aspiraba a serlo) en la sociedad rosarina de comienzos del siglo pasado establecía como dignos de preservarse durante las apariciones y 
en los comportamientos en público eran violentados por la incultura.

Durante la entreguerra, en su uso corriente los agentes letrados aplicaron este vocablo a la hora de definir conductas que no se condecían con los parámetros comportamentales establecidos como correctos o normales a partir de las categorías de clasificación sociocultural de los grupos dominantes (elites). Asimismo, el vocablo incultura fue empleado para englobar prácticas que no se ajustaban o que contradecían las reglas de juego (normas tácitas) de un espacio social específico. ${ }^{11} \mathrm{La}$ aparición de los comportamientos calificados como incultura suponían interacciones sociales y perceptivas entre dos esquemas culturales presumiblemente diferentes, cuando no antagónicos, activados por agentes sociales análogamente diferenciados. La incultura halló expresión en los comportamientos que resquebrajaban las expectativas que las elites proyectaban sobre los sectores populares y sobre los miembros más jóvenes de su propio grupo social. Éstas expectativas modelaban a los sectores populares como un alter imaginado a partir de algunos los elementos positivos del yo de la elite. Esa elaboración requería, sin embargo, el desmontaje o la disminución de ciertos atributos, sobre todos aquellos que definían la potencia y el carácter activo de la elite. El yo de la elite se sobreimprimía, subyugado, oprimido, expropiado de su fuerza y definición, a los sectores populares.

En su mayor esfuerzo de adaptación o aculturación a los parámetros de conducta establecidos como "correctos", los sectores populares sólo pudieron asemejarse relativamente a quienes habían sancionado la dignidad de esos paradigmas. Siempre existió un excedente diferenciador que hacía incompatible la homología plena entre ambos sectores. La asimilación total de los sectores populares a la elite fue un proceso que obviamente quedó interdicto. Las marcas de origen -estigmas socialmente construidos- pudieron ser reconocidas pese a una trayectoria social y moral exitosa del agente subalterno, orientada por las normas de los dominadores. ${ }^{12}$ Borrar la información social del origen, grabada en el habitus a 
IMÁGENES, JUEGOS, RITUALES Y ESPACIOS...

través de la hexis corporal y el ethos cultural, fue una de las mayores dificultades que supuso el sinuoso camino del ascenso social, tan característico de la Argentina Moderna. ${ }^{13}$ El sujeto debía objetivarse más allá y por encima de su recorrido social, aparentando un efecto ingénito y siempre igual a sí mismo, que lo colocaría (sin colocarlo) en el lugar social que había alcanzado (sin alcanzarlo) y haciendo propias (sin apropiarse) las maneras de conducirse de esa posición social. Aunque esta premisa restrictiva tendió a flexibilizarse a partir de la masificación de la sociedad acaecida luego en la década de 1940, estos signos avivaron algunos juegos sociales de las dos décadas precedentes.

En el período de entreguerras, las expectativas que la elite rosarina proyectó sobre los sectores populares fueron proclives a ser desbaratadas durante las presentaciones públicas y en los espacios donde ambos grupos podían ocasionalmente entremezclarse e interactuar. En líneas gruesas, podría decirse que esto ocurrió en todo lugar donde la concentración y la proximidad (a veces hacinamiento) de los agentes fuese lo suficientemente marcada para escudar en el grupo la conducta inapropiada o para producir formas comunicativas de interacción habilitadas por cierta cercanía física. Ese contacto casi nunca fue resultado de la voluntad de los agentes que lo construyeron, sino de las reglas de ingreso y egreso de los espacios que ocuparon. Los caminos de la difusión social de algunas prácticas y la imposibilidad de tabicar por completo los diversos espacios sociales, a partir de una sociedad configurada como una red de interdependencias dinámicas y múltiples produjeron roces, fricciones y contactos no siempre planificables, aunque paulatinamente ritualizados. En estos conflictos menos evidentes que las confrontaciones abiertas, pero mucho más permanentes que ellas, se pusieron en juego esquemas culturales y principios de agencia que establecían relaciones a partir de juegos del lenguaje, la escenificación teatral y los aspectos lúdicos de la cultura. ${ }^{14}$

La llamada incultura apareció, fundamentalmente, en los espacios públicos (calles, parques, plazas, balnearios), en los 
medios de transporte (tranvías y ómnibus), etc. La incultura bajo un punto de vista fenomenológico tendía a aparecer encarnada en un tipo de agente social particular que había adquirido derecho a recorrer el espacio público, pero que aún no había interiorizado las maneras (reglas) de hacerlo correctamente (valoración). La incultura siempre fue protagonizada por hombres y sus secuelas se dispararon sobre las mujeres, los niños, los animales y los objetos inanimados (en general bienes materiales o simbólicos cargados de cierto interés social), todos ellos incapaces de defenderse. Así, la incultura se alimentaba de los agentes que la evocaban con sus prácticas, con sus artes de hacer, pero, su mayor dependencia se establecía con respecto a quienes etiquetaban las prácticas bajo ese rótulo. Aquellos que eran capaces de hacer cosas con las palabras, ${ }^{15}$ de crear mundos y figuras donde sólo había desorden, de ponerle nombre a aquello que no lo tenía y que por eso mismo atemorizaba, de articular y moderar los ecos enervantes de la voz "caos". Lamentablemente, el único insumo para el tratamiento de estos encuentros culturales del que dispongo son las huellas escritas que de ellos han quedado. ${ }^{16}$ Marcas narrativas que no especifican la singularidad de estos eventos, procediendo dentro de los marcos abstractos en busca de establecer estereotipos y generalizaciones sociales.

Esos encuentros se producían en la ciudad de Rosario. Hacia 1920, el proceso de segregación espacial iniciado en 1880, había invertido su dirección pasando el centro a convertirse en el área de distinción de la elite y las áreas suburbanas en la locación mayoritaria de los sectores populares. ${ }^{17}$ Posiblemente, la incultura no sólo dominara en los espacios públicos localizados en el centro de la ciudad. Si nos dejamos llevar por los relatos literarios y periodísticos de la época era mucho más frecuente y hasta cotidiana en la periferia urbana, donde las relaciones sociales no estaban pautadas ni por los ritmos ni por las interdependencias que imperaban en el centro. No obstante, las manifestaciones de incultura producidas en el centro eran las que más llamaban la atención y preocupaban, tanto a los miembros de la elite como a los mediadores culturales de 
IMÁGENES, JUEGOS, RITUALES Y ESPACIOS...

variada prosapia (periodistas, escritores, etc.). Esta inquietud obedecía a que las presentaciones públicas en áreas centrales debían ser reguladas, la imagen de la ciudad y de toda la sociedad rosarina se ponía en juego allí. Conductas inapropiadas en espacios normalizados daban motivo a un indeseable efecto de contaminación. A partir de esos eventos podían ponerse en marcha los juicios pars pro toto, propios de la metonimia. Se temía por lo que pudiesen pensar de la cultura de Rosario los extranjeros y los habitantes de la Capital Federal (Buenos Aires), a partir de esas "bochornosas" manifestaciones, minoritarias pero estridentes, de la incultura. La aparición pública de la incultura borraba toda sombra de distinción.

A pesar de estas prevenciones, la elite usufructuaba de la reposición ritual de estas prácticas captadas y matrizadas lingüística y fenomenológicamente. A partir de instituir el sentido de la incultura, como ingobernabilidad, falta de disciplina, costumbre impropias y licenciosas a las que se entregaban los sectores populares, las elites evadían cualquier proximidad o contaminación respecto a esas prácticas sociales. Al mismo tiempo, trazaban su propia imagen a partir del negativo de esas prácticas, exorcizándose de los fantasmas incultos que imaginaria o realmente pudieran afectarlas.

Así la incultura era un concepto definitorio para mantener los estándares de la distinción social construidos por las elites, se trataba de un conjunto de prácticas que este grupo social debía evitar a cualquier precio. Pero que de producirse, necesariamente debía haber sido por obra de "otros", de las masas que se cobijaban en el anonimato y no de las distinguidas familias de Rosario. Ellas aborrecían lo ignoto, lo secreto, lo vulgar, muy por el contrario se solazaban de ser nombradas en toda crónica periodística que retratara cualquier evento de buen tono del que tomaran parte. ${ }^{18}$

Al tanto de estas prevenciones generales, obsérvese cómo estas lógicas de atribución de sentido sobre la configuración y las relaciones sociales en la ciudad de Rosario entre 1910 y 1945 cobraron forma en el mundo dominado por el sentido práctico. ${ }^{19}$ La cartografía que pretende describir este artículo remonta estas 
consideraciones generales, para posteriormente adentrarse en algunos de los ámbitos en que se producía la incultura. En ese marco, se analizará la incultura en las calles, los espacios públicos (espacios abiertos) y el interior de los transportes populares (espacios acotados). La intención será penetrar hasta donde sea posible en la gramática que rige estos intercambios, las estrategias que a ella se sobreimprime y en las atribuciones de sentido que respecto a estos encuentros realizan los agentes a partir de lógicas de codificación y decodificación de la información (identidad) social. ${ }^{20}$

\section{Gramáticas y juegos en la incultura.}

Estrategias para la construcción de espacios abiertos de interacción

Las calles fueron uno de los teatros de las puestas y apuestas de la incultura. Allí, estas prácticas fueron encarnadas por la patota. Tal el término empleado por La Capital, el periódico de mayor tirada en la época de Rosario, para designar a un grupo de muchachos jóvenes o menores que caminaban por las calles y veredas de la ciudad como una especie de escuadrón desordenado, permítaseme el oxímoron. Posiblemente estos varones jóvenes estuvieran enlazados por vínculos de residencia, amistad o parentesco, pero la conducta aglutinante del grupo consistía en deambular sin rumbo definido por las calles. La patota promovía algunos altercados, la esencia de su accionar era provocar, atentar contra la propiedad y terceros. Para el historiador, estos grupos sociales resultan difíciles de asir, su accionar, como un destello en la oscuridad, es lo único que emerge ante nuestros ojos condenados a iluminar y ensombrecer, a develar y, con el mismo gesto, ocultar. ${ }^{21}$ Casi todo lo demás respecto a ellos es desconocido o materia de especulación. Sólo puede saberse a qué tipo de actividades se entregaban y cuántas molestias o daños causaban. Difícil resulta conocer el sentido de esas acciones. El presente artículo pretende indagar justamente sobre ese punto obscuro, casi mantenido en secreto por los administradores de las 
IMÁGENES, JUEGOS, RITUALES Y ESPACIOS...

clasificaciones de las prácticas sociales, quienes etiquetaban a algunas de ellas como incultura, problema que, además, escapó a las mallas interpretativas del análisis historiográfico. ${ }^{22}$ Aquí, la búsqueda comienza interrogándonos sobre las condiciones de posibilidad de los enunciados que refieren a la incultura. La intención es transformar los datos en un problema.

En el registro documental consultado, la patota irrumpe recorriendo las calles de Rosario hacia 1916. La prensa indicaba a la policía la necesidad de reprimir a estos grupos. Aquellos "muchachos traviesos" ocasionaban daños materiales, generando intranquilidad entre los vecinos. Por regla, sus erráticos recorridos eran nocturnos y sus "atentados" no eran del todo temerarios, aunque en ocasiones cometiesen algún delito. La alarma de los vecinos obedecía sobre todo a los ruidos. A comienzos de siglo, las patotas frecuentaban distintas zonas de la ciudad, pero preferían el centro. La falta de temor ante las autoridades puede ser una muestra del desconocimiento de las mismas o de un estatus social entre sus miembros que les permitiera evadir los castigos. ${ }^{23}$

En 1927, la prensa no era tan concesiva con los "muchachos traviesos". El mismo periódico intuía en la patota el germen del crimen. Detrás de un aparente esparcimiento se ocultaba un submundo que atemorizaba a los periodistas $\mathrm{y}$, presumiblemente, a sus lectores. El comportamiento que contravenía a las reglas era capaz de remontar el camino del delito. Las reuniones callejeras de jóvenes no sólo alteraban la paz de los vecindarios sino que imperceptiblemente se habían convertido en escuelas del crimen. ${ }^{24}$

En el transcurso de esa década (1916-1927), el radio de acción de la patota había variado. El centro era más inaccesible para las prácticas que transgrediesen las normas. Entre sus motivos visibles podemos enunciar el reforzamiento de la vigilancia y la segregación espacial de los sectores populares a la periferia, entre los invisibles el alargamiento de las cadenas de interdependencia y el consecuente disciplinamiento social. ${ }^{25}$ En cambio los suburbios se ofrecían más propicios. Hacia fines de la década de 1920 y principios de la siguiente, las patotas se 
apostaron en las esquinas, en una especie de gesto de demarcación territorial. Al parecer, esto constriñó sus recorridos. Pese a la radicación de la patota en el barrio, su comportamiento resultó menos agresivo que el de los "muchachos traviesos" que 1916 asolaban el centro. En la naciente periferia de la ciudad se limitaron a insultar y molestar a los transeúntes. ${ }^{26}$

La consideración de la cultura letrada sobre la patota había cambiado de manera paradójica. Al mismo tiempo que estos grupos se radicaban en la periferia y morigeraban sus escarceos con los transeúntes, la prensa comenzaba a insinuar que sus agentes militaban en las filas del crimen. ¿Esta transformación mostraba una fidelidad a las mutaciones del referente al que se aplicaban los vocablos patota e incultura o se debía antes a una metamorfosis de los esquemas perceptuales de la prensa? ¿Estamos frente a un problema semiótico o semántico, el sujeto o el objeto del enunciado ha variado su posición? Difícilmente los razonamientos binarios puedan analizar la complejidad de estas transformaciones. Establecer una combinación de ambas perspectivas puede arrojar mayor luz. Revisemos aún, otro testimonio.

Otra de las actividades frecuentes de la patota fue la de proferir piropos. Aunque el grado de incultura atribuido a los integrantes de estos grupos hacía que la galantería se convirtiese sin mediación en grosería. ${ }^{27}$ Durante los primeros años 1920s., en las calles céntricas se daban cita los "piropeadores faltos de toda caballerosidad". Éstos se concentraban en calle Córdoba, arteria que emulando a la Florida porteña fue instituida en peatonal después de las seis de la tarde. ${ }^{28}$ Este hecho convertía a la calle en locación propicia para los hombres que desearan ver pasar jovencitas de a pie al atardecer. Al iniciarse los años 1930s., las patotas eran más frecuentes en los barrios que en el centro. Pero no sólo su ubicación había variado, también sus actitudes. Observemos más de cerca estos cambios. ${ }^{29}$

El desplazamiento del centro a los barrios no implicaba sólo una localización periférica de la patota, atendiendo a la extensión de la ciudad y a la paulatina configuración de esas 
IMÁGENES, JUEGOS, RITUALES Y ESPACIOS...

formaciones socio-espaciales denominadas barrios. Esta reubicación estableció otros vínculos con la sociedad circundante y, por lo tanto, otras reglas de comportamiento. Si en el centro los jóvenes que residían en la periferia podían entregarse a ciertos atentados contra la propiedad, en los barrios, núcleo de residencia y vecindad de sus familias, ellos debían mesurar su comportamiento. Con el correr de los años 1920s., el centro se convirtió en un espacio scópico y simultáneamente impersonal y anónimo. Para quienes vivían en el centro, la periferia se cargó de los atributos de lo desconocido, la oscuridad y la hostilidad. Los barrios se hallaban en conformación, la prensa los conocía poco y las autoridades municipales menos, un mundo ignoto y misterioso, cuyas prácticas eran más imaginadas que verificadas. Una parte de la ciudad que no contaba con los acondicionamientos urbanos necesarios, donde la civilización junto con la urbanización eran dos procesos encomendados al futuro. El desconocimiento sobre las actividades desarrolladas por los sectores populares en la periferia, segregados del centro residencial de las elites, preocupaban antes por incertidumbre e ignorancia que por sus características socioculturales concretas.

Los jóvenes que vivían en los barrios podían calzarse un traje de domingo e integrarse como un átomo del flujo peatonal sin marcas particulares. Aun así, cometer desmanes en el centro, un área especialmente vigilada, no era admisible más que para individuos o grupos minoritarios. Allí, la patota era demasiado visible y localizable. Incurrir en conductas patoteriles en áreas donde los grupos de encuadramiento social y apoyo habían sido erradicados de sus residencias incrementaba la posibilidad del absurdo y la desprotección. Entretanto, en la comunidad pequeña del barrio se establecían relaciones cortas (cara a cara). Si bien resultaba un mundo conocido, justamente por ello era inmune a los ataques de las patotas, pues en el las relaciones, interdependencias e informaciones fluían y tejían lazos socioculturales estables. Aunque en los suburbios, una red de relaciones amparaba y sostenía las fórmulas de la incultura, éstas no podían trasvasar ciertos límites si no se quería dañar el 
vínculo social comunitario del barrio. Si acaso la vigilancia del centro cedía era factible realizar acciones que implicaran violencia física, mientras que en el barrio convenía restringir la agencia a la violencia simbólica. ${ }^{30}$ Sólo si la provocación verbal era contestada con herramientas extrañas a las reglas del juego (violencia física) era posible que la acción derivase en otro tipo de componenda. Una acción decidida por la salvaguarda del honor grupal, los parámetros de identidad, las expectativas de rol, la alienación del agente en el grupo, el repertorio de retruécanos $\mathrm{y}$, especialmente, por las circunstancias históricas que mediaran el encuentro, muchas veces inaccesibles para el historiador.

La codificación de estos intercambios era tácita, pero debía ser rigurosamente puesta en acto en los encuentros fortuitos. Sin embargo, para los excluidos de esos códigos y del espacio social en el que circulaban, estos grupos eran impredecibles, irracionales, peligrosos y violentos. Por lo tanto era comprensible que, pese a la morigeración de la conducta de la patota, la prensa las considerara como invernaderos del crimen. Sin embargo, no fueron siempre estos agentes sociales disolutos los promotores exclusivos de los altercados. Muchas veces, las víctimas de estas agresiones verbales, pese a identificarse con la cultura y la civilización, no conseguían soportar la humillación proferida sobre su dignidad por un subalterno en pleno espacio público -a la vista potencial de sus iguales. El desbaratamiento de su identidad, de las proyecciones y relaciones de su rol social con respecto a la subalternidad del agresor, componía un cuadro que incitaba a la violencia. Si bien ésta era el último recurso para corregir el desorden social procurado por las interacciones con la incultura y sus agentes propagadores.

Hacia 1935, reaparecieron referencias a patotas nuevamente emplazadas en la primera ronda de bulevares. El tono sin embargo difería del adoptado en los años anteriores. Se guarda silencio sobre derivaciones delictuosas. Tampoco se exhibía gran preocupación por estos grupos. Los disturbios que provocaban revestían envergadura, pero atacaban la propiedad y las cosas, dejando libres a las personas. No utilizaban el 
IMÁGENES, JUEGOS, RITUALES Y ESPACIOS...

lenguaje, prefiriendo servirse de la acción de desordenar y dañar objetos. Por lo demás, ante el paso de personas ajenas al grupo se mantenían en su sitio, mostrando total desparpajo, impidiendo el tránsito sin vergüenza ni temor. No existen referencias que permitan asegurar si se producían o no intercambios verbales durante esos encuentros fortuitos. Estos grupos estaban integrados por jóvenes que expresaban de modo poco ortodoxo sus formas culturales en las calles de Rosario. ${ }^{31}$

Referencias de este tipo se prolongan en los años siguientes. Quizá podríamos agregar, en beneficio de los cronistas, que cada vez describían con mayor detalle las relaciones sociales que engendraban a la patota. La mirada de la prensa lentamente perdió su inicial halo fenomenológico y pero no el neurótico. En la medida en que la perspectiva se aproximaba a esos hombres que merodeaban por las calles reguladas por las normas y las horas como si fueran las avenidas de un carnaval, se podía dar cuenta más acabada de ellos. Esta proximidad no implicó un más amplio umbral de comprensión. Tan sólo se afinaron las descripciones, volviéndose más abundantes los detalles y las interpretaciones. Pero los motivos de estas prácticas permanecieron desconocidos, incrementando tan sólo algunos de los contornos de la actividad de la patota. La prensa prefirió purificar el fenómeno recurriendo a la oposición binaria cultura vs. incultura. Encubriendo así su papel en tanto productora, reproductora y difusora de estas antinomias clasificatorias.

Las patotas modificaban sus hábitos, al mismo tiempo los periodistas las conocían mejor. Sabían de los ardides que utilizaban para escabullirse en el anonimato y las sombras de una ciudad cada vez más grande; cuáles eran los días y los lugares en que estaban más activas. También reconocieron que la patota no era ya un grupo fijo, apostado sobre las calles al aguardo de un transeúnte desprevenido. A fines de los años 1930s., se desplazaba por las calles de la ciudad, incluso a bordo de camiones. Sobre estos vehículos asistían a excursiones y justas deportivas, desde allí descargaban sus "emociones" en forma de insultos sobre los peatones. Sin embargo, la lógica de 
estos comportamientos era un territorio inaccesible a la prensa, oscurecido por su propia mirada.

\section{Identidades sociales, honores y masculinidades en los rituales de incultura}

El uso del lenguaje agraviante hacía difícil obrar la represión debido a su carácter evanescente. Antes debía regir una prescriptiva general, que al no interiorizarse en los agentes a los que incumbía difícilmente pudiese obtener éxito. ${ }^{32} \mathrm{La}$ incultura se producía en las calles mediante el gesto, la palabra y en ocasiones concluía con la agresión física. Pero ese desplazamiento no era sólo una muestra de irracionalidad y de escasa educación, antes configuraba la puesta en acto de esquemas y recursos sociales y simbólicos aprendidos e inscriptos en la práctica de estas interacciones.

En ocasiones, esos gestos y palabras apuntaban sobre alguien que no podía ejercer su propia defensa: mujeres, niños o ancianos. Cuando se dirigía a alguien hábil para confrontar (varones adultos o jóvenes), el terreno del encuentro no siempre se resolvía en una pelea a golpes o con armas blancas. En todo caso, la provocación establecía un duelo primero discursivo, que podía sostenerse siempre y cuando ninguno de los contendores avanzara sobre los delgados límites codificados por el sentido práctico. En caso de que alguno de ellos, desbaratara los embistes verbales del otro, poniendo en evidencia su mayor pericia en ese terreno y produciendo un desbalance notable en el equilibrio y la tensión propia del juego del lenguaje, entonces la acción violenta podía sobrevenir. La resolución física del duelo verbal resulta de fórmulas y esquemas culturales asociados al honor masculino. La restitución de ese honor, al menos entre los sectores populares, sólo podía operarse a partir de la obtención del triunfo en la componenda. ${ }^{33} \mathrm{La}$ exhibición de destreza o habilidad sin resultados, en el esquema cultural de estos grupos gozaba de una escasa valoración. Quizá ésta sea una de las diferencias más notables entre el patrón tendencial de conducta 
IMÁGENES, JUEGOS, RITUALES Y ESPACIOS...

en la defensa del honor adoptado por los sectores populares y las elites.

La incultura se expresó en las plazas, paseos públicos, en hibridaciones entre la calle y la plaza o el parque. Allí podían producirse los típicos altercados a partir de los intercambios verbales, pero también "escenas vergonzosas" como la exhibición de los genitales o la realización de gestos obscenos. Este tipo de comportamientos reconocía un carácter voluntario. Era producido y calculado para horrorizar y ofender. Una acción que ponía a jugar los esquemas culturales de los receptores de la agresión: elites, clases medias. Al mismo tiempo, la teatralización elaboraba a partir de la caricatura el estereotipo que estos grupos habían proyectado sobre los sectores populares. $^{34}$

También estas acciones podían ser el resultado de las circunstancias $u$ aparecer de manera incidental. En muchos casos fue determinante la carencia de medios suficientes para la satisfacción de las necesidades fisiológicas. La falta de baños públicos y mingitorios producía actos que se contradecían con la moral pública. En 1932, en el Concejo Deliberante de Rosario se indicó la necesidad de levantar una arboleda frente a los mingitorios del Parque Independencia a fin de evitar "...la contemplación de actos inmorales e indecorosos." 35

Tras la difusión social de sus usos, parques y plazas fueron lugares de encuentro entre grupos socioculturales diversos. Allí la incultura pudo expresarse con mayor contundencia. La plaza Sarmiento fue uno de estos sitios. En sus arboledas, los jóvenes se entregaban a flirteos poco disciplinados con las alumnas de la Escuela Normal de Señoritas. ${ }^{36}$ Esta plaza era la parada de los ómnibus de larga y media distancia que arribaban a la ciudad. Además, era el sitio donde se iniciaba la calle comercial ocupada por comerciantes de orígenes étnicos comunes. Su mala iluminación y el hecho de constituirse en una suerte de no lugar, en el que nadie tenía relaciones sociales estables, la convertían en un sitio para la comisión de esos atentados contra la moral. Los bancos de la plaza, ocultos bajo el espeso follaje constituían el lugar propicio para los escarceos amorosos. Hombres y 
mujeres acodados en esos sitios se permitían ir bastante más lejos de los besos y las caricias. Además, el muro de la Escuela Normal que dividía la plaza Sarmiento era transformado "por personas inescrupulosas en mingitorio" ${ }^{37}$

Estas manifestaciones se combinaban con la afición de los jóvenes varones a entorpecer el desplazamiento de las señoritas por las calles de la ciudad. Parcialmente, se trataba de una actualización del estatus de inferioridad que la mujer poseía respecto a los hombres, más allá de las adscripciones sociales que revistieran cada uno de los géneros que protagonizaran los encuentros. ${ }^{38}$ Por ejemplo, los vendedores de rifas, quienes no gozaban de una distinguida posición social, molestaban a las paseantes con “...actitudes incorrectas y frases hirientes. Las principales víctimas suelen serlo las mujeres acaso porque no son susceptibles de reacciones enérgicas." ${ }^{39}$ A actividades semejantes se consagraban también los puesteros del Mercado Central. $^{40}$

En general, estas acciones tenían por objeto ridiculizar o poner en aprietos a un partenaire circunstancial frente al grupo de pertenencia. La finalidad declarada: seducción o conquista quedaba por completo descartada. Era improbable acceder a ella por esos medios, incluso cuando el desbalance de la posición social entre los agentes no fuera pronunciado. Antes un componente de autoafirmación masculina y alienación grupal, no exento de elementos homoeróticos, establecen un principio de interpretación sobre estos comportamientos. ${ }^{41}$ Los jóvenes dedicados a la exhibición pública del piropeo empleaban estas prácticas a fin de afirmar una masculinidad que como toda identidad era inestable. Afirmaban sus valores de virilidad y atracción por el sexo opuesto con cófrades de grupos formados durante el tiempo libre compartido en las calles. Estas conductas estaban dirigidas antes a los compañeros del mismo sexo que a las jovencitas que transitaban por las aceras. La acción verbal inscripta en estas manifestaciones ocasionalmente comportaba cierta humillación sobre el género opuesto, una expresión de las formas de la dominación masculina. 
IMÁGENES, JUEGOS, RITUALES Y ESPACIOS...

Los episodios de incultura no sólo constituían un ritual de exhibición ritual de la masculinidad, también podían prologar episodios que tendían a expropiar esa masculinidad a quienes la ponían en acto mediante la interacción con una que pasa. La conscripción obligatoria era uno de esos momentos, en sus vísperas los jóvenes veían descender una amenaza a su masculinidad. En el servicio militar la potencia, la libertad y el desenfreno eran absorbidos y reencauzados por las demandas de una institución total. ${ }^{42}$ Los jóvenes que llegaban a la ciudad para prestar servicio en las unidades militares (Regimiento 11 de Infantería) se entregaban a un relajamiento de las costumbres en el trayecto. Todo aquello que la institución reprimiría podía ser dejado en libertad en las horas previas, casi como si se tratara de la última vez. ${ }^{43}$

Los jóvenes provenientes del interior de la provincia, al subir al tren que los conduciría a Rosario a fin de enrolarse "agredieron de palabra y obra" a los viajeros "...destrozándoles los sombreros, manoseándoles y escarneciéndolos prevalidos de la impunidad que les asegura la circunstancia de ser más numeroso el grupo de conscriptos que el de pasajeros. Por cierto que el incidente estuvo a punto de tener un desenlace trágico, pues sólo a costa de grandes esfuerzos se evitó que uno de los pasajeros agredidos hiciera uso de un revolver que esgrimió con la intención de hacerle justicia a su honor por su mano." ${ }^{44}$

Destrozar los sombreros, atacar a los circunstantes que nada podían hacer sobre un tren en movimiento, frente al crecido número de agresores, fueron las actitudes que asumieron los futuros defensores de la patria. No todo el pasaje podía transformarse en objeto de estas burlas que, por adelantado, retribuían las humillaciones que los conscriptos padecerían tan pronto como ingresaran al batallón. Los sombreros que formaban parte del atuendo digno, de las vestimentas apropiadas para salir a las vistas de otros, fueron tomados como símbolos para el ataque de quienes pronto sólo podrían lucir su cabeza rasurada y uniformes idénticos. 


\section{La incultura en los transportes públicos: espacios acotados de interacción}

Desde 1905, Rosario contó con un sistema de tranvías eléctricos y desde 1924 con uno de ómnibus. Ambos medios fueron espacios propicios para la puesta en marcha de las artes de la incultura. Como se ha visto, la extensión de la ciudad ocasionó la diversificación social de sus áreas periféricas, buena parte de esta población se veía obligada a concentrarse en los medios de transporte público. El aislamiento, hacinamiento, extensión de los recorridos, el carácter público y la baratura del pasaje mezclaron agentes de diverso tipo social, etario y genérico. Estas diferencias pusieron en marcha algunos de los mecanismos descritos arriba. La coexistencia en un ámbito acotado inspiro algunas interacciones sociales, veamos cuáles fueron sus expresiones.

Desde los primeros años 1920s., el transporte público de pasajeros atravesó un proceso sostenido de masificación. La estadística muestra que durante 1908, cuando la red tranviaria alcanzó su funcionamiento pleno, se cortaron 14.985 .685 boletos. Para 1920, la cifra se había duplicado. En 1925 se pagaron 53.341.019 viajes. Este incremento del tráfico de mujeres y hombres a través de aparatos y vías generó obstrucciones y demoras de consideración. En esos trayectos accidentados por el cambio de coches, las vías en mal estado, las huelgas y lockouts, y la lenta marcha de los móviles se produjeron interacciones no siempre valoradas positivamente por la prensa. ${ }^{45}$

En 1923, cuando se cortaban 47 millones de boletos tranviarios al año, la prensa presentó una reseña de estos incidentes. En esos cuadros, la incultura era un componente habitual, casi obligatorio. La estrategia de presentación de esas conductas anómalas pretendía evitar la naturalización de sus hábitos. Estas acciones se producían los días festivos y domingos, cuando grupos de jóvenes concurrían a los espectáculos futbolísticos atestando los tranvías de pasajeros e incluso asentando sus cuerpos en los estribos o el techo de los 
IMÁGENES, JUEGOS, RITUALES Y ESPACIOS...

coches. Se narraban las alternativas de "individuos inadecuados" que "daban rienda suelta a sus instintos, entregándose a procaces expansiones."

Muchos jóvenes que abandonaban los estadios futbolísticos y utilizaban el tranvía como medio para llegar a sus domicilios eran los promotores de la incultura a bordo de los vagones. La conducta inapropiada consistía en mantener vigentes reglas de un espacio social que se había abandonado. $\mathrm{Si}$ en los estadios el lenguaje procaz constituía un código de chanza y agresión entre los simpatizantes de los diversos equipos, en el transporte esos modos debían quedar anulados, suspendidos. Los hombres no ascendían solos a los coches, trasladaban consigo la sociabilidad del estadio. Los asientos eran ocupados por niñas y mujeres, frente a las cuales las expansiones inmoderadas resultaban inapropiadas, debido al principio de protección que las formas caballerescas establecían respecto a ellas. Las expresiones utilizadas para estigmatizar a quienes así viajaban contabilizaron varios giros: "gente desprovista de toda cultura", "elementos cuya compañía resulta desagradable", desvergonzados y, finalmente, la voz cafres que significaba inculto. ${ }^{46}$

Una vez más, en el tranvía al igual que en las calles, los protocolos de la incultura se reproducían. Agentes activos, emisores o codificadores, dependiendo del rasero teórico con que los clasifiquemos, eran grupos de hombres jóvenes. Agentes pasivos, receptores o decodificadores: mujeres y niñas. Las formas de presentación, lugares públicos, en este caso, coches cerrados del transporte público. El mensaje consistía en expresiones soeces, maneras incultas, provocaciones, pendencias y riñas. La codificación era realizada desde el espacio simbólico de la cultura popular, universo de sentido concebido por sus descriptores letrados como no regulado y anómico. Mientras, la decodificación se efectuaba desde una cultura normalizada, atravesada por el respeto a las formas de urbanidad presentes en los modos adecuados de conducirse en público. Esta simplificación abstracta evidencia algunas de las posibles configuraciones de sentido establecidas en los 
intercambios, presuntamente simétricos, de la cultura y la incultura. En este esquema la simetría y exclusión de ambos polos (cultura e incultura) sería absoluta, la comprensión se depositaría en la decodificación y la incomprensión o lo incomprensible en la codificación. El mensaje de este modo sería procesado (codificación), puesto en circulación y recibido (decodificación). Habría, no obstante, entre ambos polos de la relación una incomprensión insuperable. ${ }^{47}$ Como es sabido, las modelizaciones abstractas sólo se corresponden relativamente con las prácticas.

Entre 1922 y 1923 se cursaron solicitudes para la circulación de ómnibus. El tranvía era lento y sus redes resultaban insuficientes para una ciudad en permanente expansión. El ejemplo bonaerense indicaba el camino. Si la red de subterráneos era impracticable, debido a los trabajos y costos que entrañaba, al menos Rosario podía implementar el servicio de ómnibus. ${ }^{48}$

En 1925 el servicio fue librado al uso público. Al año siguiente fue regularizado por la Ordenanza de circulación de ómnibus. ${ }^{49}$ En 1929 se estipularon los recorridos y los horarios de las líneas. ${ }^{50}$ Ese año, los signos de incultura también pudieron apreciarse en los nuevos transportes, ${ }^{51}$ paradojalmente cuánto más se reglamentaba el servicio menos podía controlarse a su pasaje. En estos episodios apenas si se modificó el escenario. Podían producirse variaciones de grado pero no de tipo, respecto a los incidentes acaecidos en los tranvías. Los articulistas proponían que choferes y guardas mantuvieran a raya a los individuos que promovían altercados en los coches. Los empleados del transporte de pasajeros atravesaron un rígido proceso de disciplinamiento en el momento de acoplarse a sus funciones. Junto con el personal doméstico, el trabajo de choferes y guardas estaba seriamente regulado por las ordenanzas. Esta atención, aparentemente excesiva, se debía a que estos empleados entraban en contacto permanente con el público, estando obligados a guardar las formas culturales establecidas. ${ }^{52}$ Los choferes de ómnibus fueron alcanzados tardía e incompletamente por los componentes disciplinarios de 
IMÁGENES, JUEGOS, RITUALES Y ESPACIOS...

estas normativas. Mientras, tranviarios y taximetristas observaron un trato más regular con los pasajeros, los conductores de ómnibus seguían empleando un lenguaje y unos modos conceptuados como inapropiados. En los ómnibus, las damas y las niñas, además de tolerar las manifestaciones de incultura de los hombres del pasaje, debían someterse a las de los guardas y choferes del servicio. ${ }^{53}$

Si bien los choferes podían participar de los actos de incultura, éstos no debían trasvasar los límites de la oralidad. La continuidad de su trabajo estaba en juego. Cuando los actos de incultura irrumpieron en los ómnibus, conductores y guardas adoptaron una actitud prescindente, prefiriendo mantener una prudente distancia frente a altercados y groserías. Apenas si podían lidiar con su propia disciplina, poco les interesaba mantener el orden en los coches. En el ocaso de la primavera de 1934, un violento episodio acaecido en el ómnibus de la línea 11 hizo explícitos los motivos de esta determinación. ${ }^{54}$

La incultura podía generar episodios violentos, como el descrito arriba, pero esa no fue la regla. Las conductas reñidas con los códigos de "normalidad" no alcanzaron tales extremos, manteniéndose en un campo más sutil y ajeno a la intervención de la policía y la justicia. Ni la conflictividad en el trayecto de la línea $\mathrm{n}^{\circ} 11, \mathrm{ni} \mathrm{su}$ incremento en vísperas del verano eran casuales. Luego de 1930, el recorrido de sus coches era el único que unía la zona céntrica de la ciudad con los Nuevos Mataderos Municipales, los baños del Saladillo y el Frigorífico Swift. ${ }^{55}$ En primavera y verano el público de los baños se ponía en marcha desde el centro hacia el sur de la ciudad. Si bien su extracción social no era tan selecta como en las primeras décadas del siglo $\mathrm{XX}$, la posición social y el objetivo del viaje de estos pasajeros difería de las que movilizaba a los obreros en la misma dirección. Unos se encaminaban a disfrutar de su tiempo libre, mientras los otros a padecer su tiempo de trabajo. Unos viajaban hacia el ocio y otros hacia la fábrica, aunque ambos debían descender del coche a menos de un kilómetro de distancia.

Como pude imaginarse, los interiores de esos tranvías fueron poblados por agentes diversos y el trayecto no siempre 
estuvo acompañado del buen tono en el trato social. Hacia el frigorífico, el matadero y otras actividades del área se movilizaban a diario 3.000 trabajadores. En verano los bañistas de Saladillo eran numerosísimos. Entre las dos y las seis de la tarde se veía pasar repletos a los coches que iban del centro al sur y vacíos a los que volvían. Los pasos a nivel y las barreras dilataban el viaje, impacientando a algunos componentes del pasaje. $^{56}$

Estos episodios siguieron repitiéndose, las características generales del teatro provisto por el transporte y de los agentes de la incultura han sido aquí tematizadas. Al menos hasta la culminación de la entreguerra, este tipo de problemáticas continuó aquejando a damas y señoritas, y a esa parte del pasaje que quería distinguirse de los modos incultos, pero, especialmente, a las plumas de los redactores de La Capital.

\section{Conclusiones}

Durante la entreguerra, los lugares de reunión y encuentro se transformaron, según la prensa rosarina, en ámbitos de incultura. Los comportamientos de algunos hombres en esos espacios fueron frecuentemente anotados. La disciplina, la autocontención de las reacciones violentas o fuera del marco de reglas propuestas por ciertos espacios sociales de convivencia, tardaron en instalarse de manera definitiva entre los agentes sociales. Pero como se ha visto en este artículo, al ritual de la incultura, formalizado por protocolos claros y estables se le oponía el ritual de su condenación y censura pública. ${ }^{57}$ En ningún caso el orden estaba en juego y el funcionamiento cíclico de estos rituales aseguró su perduración.

Los jóvenes de los sectores populares desconocían voluntaria o involuntariamente las reglas de determinados ámbitos, simétricamente la prensa narraba los hechos provocados por ese desconocimiento tipificándolos como incultura. En esas notas, la cultura de los sectores populares se constituía a través de su negación. Durante los años 1920s., las representaciones periodísticas tendían a separar la incultura del 
IMÁGENES, JUEGOS, RITUALES Y ESPACIOS...

delito. Los jóvenes que atentaban contra las normas no eran necesariamente delincuentes, ni se comportaban de manera inapropiada en todos los planos de su existencia. La defensa de la sociedad de la que participaba el periódico no era equivalente a la instrumentada frente a otros disturbios o alteraciones del orden como la huelga o el crimen organizado. ${ }^{58}$ También esos episodios fueron clasificados como incultura, pero su peligrosidad nunca fue minimizada, esa inversión de las normas podía hacer de la comedia un drama y conducir al orden a un nivel de organización distinto. ${ }^{59}$ La posición de los periodistas respecto a los actos de incultura si bien era condenatoria, ofrecía mayor flexibilidad. Se trataba antes de una defensa de las reglas y de las relaciones sociales correctas que de una defensa del cuerpo social. La amenaza de la incultura era crónica, pero su potencia sólo relativa. Aunque no planificada, su carácter imprevisible sólo podía acarrear inversiones parciales y localizadas del orden. Los redactores de La Capital conocían este doble carácter de los hechos que iguales a sí mismos reseñaban ritualmente año a año.

Las formulaciones que efectuaron los periodistas, las elites, las autoridades y los mediadores culturales sobre la incultura cargaban a esas prácticas de una contra-aura. ${ }^{60} \mathrm{En}$ el ámbito de la incultura, por consiguiente, no había reglas, todo quedaba librado a la espontaneidad, a la risa, al movimiento corporal y, en un tributo al cartesianismo, a la ausencia de razón o a la más completa e inexplicable irracionalidad de los apetitos corporales. Como he intentado demostrar, la incultura obedecía a un conjunto de protocolos de presentación y reglas de interacción que involucraban el aprendizaje de formas culturales, aunque esta experiencia no se realizara ni transmitiera a partir de los formatos de la cultura alta o media. La incultura puesta en acto en las calles, los transportes públicos, las plazas, los parques, etc., estaba altamente codificada para ejecutarse y ser reconocida. La particular escenificación de los agentes que la actualizaban, apuntaba a herir la sensibilidad de sus decodificadores presumiblemente cultos. Éstos, aunque siempre se mostraran extraños al código de la incultura, lo decodificaban 
como una agresión velada, como un embate contra su identidad social, perpetrado por aquellos que reclamaban para sí una identidad amorfa que traicionaba unos códigos sociales jamás contratados y apenas sutilmente impuestos.

La incultura y la cultura sólo fueron pares purificados y opuestos en el sistema de signos y de atribuciones de sentido ideados por los grupos letrados, en pos de ordenar y clasificar un mundo al que rechazaban y negaban. Las prácticas así tipificadas circularon en un espacio social ubicado en medio y debajo de estas oposiciones, un ámbito menos nítido y asible. Ese universo configurado por el sentido práctico, no se rigió por las clasificaciones de los grupos que procuraban con un movimiento expropiar y monopolizar el poder de nominación. ${ }^{61}$ Las elites y los mediadores culturales reclamaban la capacidad de sobreimprimirle, desde las páginas de sus periódicos y documentaciones oficiales, un sentido a prácticas de autoafirmación subordinada y de una conflictividad que, bajo el ropaje de esas fórmulas, se tornaba casi invisible.

Las lógicas de la incultura eran informales, como todo universo configurado a partir de interdependencias y prácticas no completamente panificables, se nutrían del caos y el orden que producía el establecimiento de rituales de encuentro de diversos grupos socioculturales, y de las cadenas de interdependencia que mediaban esas relaciones. En esos episodios evanescentes y casi inasequibles para el historiador se jugaba la auto-representación y la representación social de los sectores populares y las elites. Los sectores populares, motejados por las elites como intemperantes, incontinentes, faltos de disciplina y de moral, adoptaban todas esas características indeseables al momento de compartir el espacio público con sus estigmatizadores. Precisamente, en los lugares y momentos en que los sectores populares debían desmentir esa clasificación denigrante, comportándose "correctamente" (lo que equivale a decir pasivamente) aceptando la subordinación social que les correspondía en las representaciones e interacciones sociales, ejecutaban artes de hacer que 
IMÁGENES, JUEGOS, RITUALES Y ESPACIOS...

contrariaban los deseos de las elites y los mediadores culturales. $^{62}$

La inestable dinámica conflicto-equilibrio pautada en las relaciones de los sectores populares con las elites, se pusieron en acto en algunos espacios públicos. Allí, el contacto era capaz de expresar, a través de signos de información social colectiva, las diferencias sociales haciéndolas, a través de las artes terrestres de la incultura, aceptables y reproducibles en un espacio-tiempo que no era de trabajo, en un tiempo libre, que en esos protocolos rituales se manifestó como un tiempo fuera del tiempo. Podríamos denominar a estas formas de interacción social, sirviéndonos del título del libro de C. Monsivais: los rituales del caos. ${ }^{63}$ Las formas de interacción cotidiana que afectan la vida de esas ciudades que se hallan en el umbral de la vida metropolitana y de la sociedad de masas. Los agentes anónimos que transitan sus calles intuyen bajo sus pies las dimensiones del abismo que comunica ese pasaje.

ROLDÁN, Diego P. Images, games, rituals and spaces. The sociocultural interactions between elites and popular sectors during the interwar. The unculture in Rosario (Argentina). História, v.28, n.2, p.683-714, 2009.

\begin{abstract}
This article discusses the forms of presentation, interaction and conflict deployed in the urban space of Rosario (Argentina) between elites and popular sectors during the interwar. Analyzed behaviors were established by the elites as manifestations of incivility. The aim is to study this set of practices trying to non exotizing from an hermeneutic and semiotic reading of its operating, protocols and socio-cultural relations. It will show how for the elites was a set of disrupted and meaningless practices, was a complex fabric of tactics and strategies of encoding and decoding of social identity. Social games produced within the framework of dynamic interaction processes based on social and power asymmetric relations. The reconstruction of these pieces of social interactions intended to unravel the meanings and operating of construction of identities, games, rituals and social spaces.
\end{abstract}


Keywords: Practices; Culture; Social relationships; Interaction; Space.

\section{NOTAS}

${ }^{1}$ Nuestra pesquisa de materiales documentales se ha concentrado en el Archivo del Concejo Deliberante de la ciudad de Rosario, fundamentalmente, en los fondos que componen los Digestos y Ordenanzas (DyO), los Diarios de Sesiones (DS HCD), los Expedientes Terminados (ET HCD), las Memorias de Intendentes (MI), los Cálculos de Presupuesto (CP) y los Anuarios Estadísticos (AE). Además, en el ámbito de la prensa hemos compulsado la serie completa de La Capital entre 1900 y 1945, el periódico de mayor tiraje de la ciudad en el período.

${ }^{2}$ FALCÓN, Ricardo La larga batalla por el carnaval. La cuestión del orden social, urbano y laboral en el Rosario del siglo XIX. Anuario de la Escuela de Historia, Rosario: Universidad Nacional de Rosario, n.14, 1989-90, pp. 207-226; FALCÓN, et al. Elites y sectores populares en un período de transición (Rosario, 1870-1900). In: ASCOLANI, Adrián (compilador) Historia del Sur Santafesino. La sociedad transformada (1850-1930). Rosario: Ediciones Platino, 1993, pp. 73-119; GAYOL, Sandra Sociabilidad en Buenos Aires. Hombres, honor y cafés, 18621910. Buenos Aires: Ediciones del Signo, 2000.

${ }^{3}$ ARMUS, Diego et al. Sectores populares y vida urbana. Buenos Aires: CLACSO, 1984; ARMUS, Diego (compilador) Mundo urbano y cultura popular. Estudios de historia social argentina. Buenos Aires: Sudamericana, 1990; GUTIÉRREZ, Leandro y ROMERO, Luis Alberto Sectores populares cultura y política. Buenos Aires en la entreguerra. Buenos Aires: Sudamericana, 1994; ROMERO, Luis Alberto y KORN, Francis (compiladores) Buenos Aires/entreguerras. La callada transformación. Buenos Aires: Alianza, 2006.

${ }^{4}$ Este artículo se basa en la última parte de mi tesis doctoral: ¿Qué hacer con el Tiempo? Intentos reguladores y estrategias de resistencia sobre los usos del tiempo libre: un campo conflicto. Los Sectores Populares de Rosario 1910-1945. Rosario, 2008. (Tesis Doctoral en Historia) FHyA - UNR.

${ }^{5}$ Sobre los vínculos entre el funcionalismo la teoría biológica y el control social ver: JONES, Gareth Stedman ¿Expresión de clase o 
IMÁGENES, JUEGOS, RITUALES Y ESPACIOS...

control social? Crítica de las últimas tendencias de la historia social del "ocio". In: Lenguaje de clases. Estudios sobre la clase obrera inglesa. México: Siglo XXI, 1989 y ELIAS, Norbert El proceso de civilización. Investigaciones sociogenéticas y psicogenéticas. Fondo de Cultura Económica: México, 1987.

${ }^{6}$ No desconozco las posibles aplicaciones del término en períodos precedentes. No obstante, aquí me detendré en la trayectoria y los usos sociales más frecuentes de esta palabra en el período bajo análisis.

${ }^{7}$ Durante este período, aunque posiblemente también desde fines del siglo XIX, el concepto de cultura se enlazó con la idea de progreso. Como el progreso podía expresarse en diversos campos de la actividad humana, el concepto se hibridaba con ellas. Podría establecerse una larga lista de fenómenos que eran revestidos por el aura de la cultura, preferimos repasar aquí sólo algunos: cultura física, cultura colectiva, cultura popular, cultura intelectual, cultura artística, etc. Cf. BURY, John La idea de progreso. Madrid: Alianza, 1971.

${ }^{8}$ PEIRCE, Charles S. Semiótica. Río de Janeiro: Editorial Perspectiva, 2003.

${ }^{9}$ AUSTIN, John L. Cómo hacer cosas con palabras. Barcelona: Paidós, 1982.

${ }^{10}$ BOURDIEU, Pierre La distinción. Criterio y bases sociales del gusto, Madrid: Taurus, 1998 y ¿Qué significa hablar? Economía de los intercambios lingüísticos. Madrid: Akal, 2008.

11 WITTGENSTEIN, Ludwing Investigaciones filosóficas. Barcelona: Altaya, 1999.

${ }^{12}$ Sobre las ideas de trayectoria moral y social ver: GOFFMAN, Erving Internados. Ensayos sobre la situación social de los enfermos mentales. Buenos Aires: Amorrortu Editores, 1984.

${ }^{13}$ Los conceptos de hexis y habitus han sido tomados de BOURDIEU, Pierre Meditaciones Pascalianas. Barcelona: Anagrama, 1999. Sobre la trayectoria y las adaptaciones del concepto de hábitus ver el artículo de WACQUANT, Loïc Habiuts. In: BECKERT, Jens y ZAFIROVSKI, Milan (editores) International Encyclopedia of Economic Sociology. London: Routledge, 2005, pp. 315-319.

${ }^{14}$ Sobre esta conceptualización ver: GOFFMAN, Erving La presentación de la persona en la vida cotidiana. Buenos Aires, Amorrortu, 1981; GEERTZ, Clifford Géneros Confusos. La refiguración del pensamiento social, In: REYNOSO, Carlos (compilador) El surgimiento de la 
antropología posmoderna. Barcelona: Paidós, 1994, pp. 66-72; MORGENSTERN, Oskar y VON NEUMANN, John The Theory of Games and Economic Behavior. Princeton: Princeton University Press, 1947.

${ }^{15}$ AUSTIN, John L. Cómo hacer..., cit.

${ }^{16}$ Para un análisis sociológico de los encuentros socioculturales ver: GOFFMAN, Erving Encounters: two studies in sociology of interaction. Indianapolis: Boobs Merril, 1961.

${ }^{17} \mathrm{El}$ proceso de segregación espacial de la ciudad de Rosario posee una complejidad que lo hace difícil de resumir en estas pocas páginas. He trabajado sobre él con mayor detenimiento en Del ocio a la fábrica. Sociedad, espacio y cultura en Barrio Saladillo Rosario 1870-1940, Rosario: Prohistoria Ediciones, 2005.

${ }^{18}$ Durante los años 1910 y 1920, las élites adoptaron la costumbre de publicitar sus viajes de vacaciones en La Capital. Simétricamente, los cronistas detallaban los nombres de las familias que participaban de eventos sociales de buen tono: inauguraciones, exposiciones artísticas, festejos patrióticos o religiosos, carnavales oficiales, etc.

${ }^{19}$ BOURDIEU, Pierre El sentido práctico. Buenos Aires: Siglo XXI, 2007.

20 HALL, Stuart y DU GAY, Paul Cuestiones de identidad cultural. Buenos Aires: Amorrortu, 2003.

${ }^{21}$ HEISENBERG, Werner Física y filosofía. Buenos Aires: La Isla, 1959.

${ }^{22}$ En este campo posiblemente la sociología haya conseguido mayores resultados. Sobre el particular consultar el libro de ALABARCES, Pablo et al. Hinchadas. Buenos Aires: Prometeo, 2005.

23 "Anoche mismo, en la esquina de las calles Dorrego y Santa Fe, en la esquina misma de la jefatura de policía, una de esas patotas apedreó a un tranvía de la línea número 5, resultando lesionado uno de los pasajeros." Las Patotas. In: La Capital 19/II/1916.

${ }^{24}$ En la década de 1920 La Capital publicó extractos de Los Apaches de París y La Escuela del Crimen ambos de Gustave Guitton. En ocasiones, las notas sobre las patotas criminogénicas fueron salpicadas por referencias a estos libros y a Los misterios de París de Eugene Sué.

${ }^{25}$ Sobre el alargamiento de las cadenas de interdependencia ver: ELIAS, Norbert El proceso de civilización..., cit. y del mismo autor La Sociedad de los individuos. Barcelona: Península, 1990. Sobre el proceso de disciplinamiento ver el clásico de FOUCAULT, Michel Vigilar y castigar. El nacimiento de la prisión. México: Siglo XXI, 1998.

${ }^{26}$ Las patotas callejeras. In: La Capital 20/X/1927.

${ }^{27}$ Piropo y Grosería. In: La Capital 28/VII/1933. 
IMÁGENES, JUEGOS, RITUALES Y ESPACIOS...

${ }^{28}$ Aspectos urbanos. La calle Córdoba. In: La Capital 12/IV/1920.

${ }^{29}$ Las patotas molestas. In: La Capital 16/XI/1934.

${ }^{30}$ BOURDIEU, Pierre y PASSERON, Jean-Claude Elementos para una teoría de la violencia simbólica. In: La Reproducción. Elementos para una teoría del sistema de enseñanza. Madrid: Editorial Popular, 2001, pp. 15-85.

${ }^{31}$ Patotas Callejeras. In: La Capital 22/III/1935.

32 Desde 1911 quedó prohibido por ordenanza proferir palabras obscenas, orinar en las calles o en cualquier paraje público, destruir árboles o plantas en las calles, plazas o paseos públicos. Palabras y Acciones indecentes. Ordenanza $\mathrm{N}^{\circ} 35$ de 1911. In Compendio de Digestos municipal publicado en el año 1931, durante la intendencia del Dr. Alejandro Carrasco. Rosario: Talleres Pomponio, 1932, p. 838.

${ }^{33}$ GAYOL, Sandra Sociabilidad en Buenos Aires..., cit. De la misma autora: Honor y duelo en la Argentina Moderna. Buenos Aires: Siglo XXI, 2007.

34 "Cierre del pasaje José María Gutiérrez por la incultura imperante y la comisión de actos inmorales", VT DS HCD 8/I/1918, f. 398. Actos de incultura en los paseos públicos. In: La Capital 20/XI/1933.

35 11/III/1932 Proyecto de Atilio De Sactis sobre la colocación de plantas frente a los mingitorios del Rosedal. In: ET HCD enero-marzo 1932, f. 620.

${ }^{36}$ Plaza Sarmiento. Atentados contra la cultura. In: La Capital 19/V/1934.

${ }^{37}$ Orín y actos inmorales en la Plaza Sarmiento. In: DS HCD 06/XI/1934, t. II, p. 1529.

${ }^{38}$ BOURDIEU, Pierre La Dominación Masculina. Barcelona: Anagrama, 2000.

${ }^{39}$ Manifestaciones de Incultura, In: La Capital 24/X/1927.

${ }^{40}$ Resabios de incultura. El respeto a la mujer. In La Capital 11/X/1928.

${ }^{41}$ WACQUANT, Loïc Why men desires muscles? In: Body and Society, n.1, v.1, spring 1995, pp. 163-180; ARCHETTI, Eduardo Masculinidades. Fútbol, Tango y Polo en la Argentina. Buenos Aires: Antropofagia, 2003.

${ }^{42}$ GOFFMAN, Erving Internados..., cit.

${ }^{43}$ Los conscriptos y los actos de incultura. In: La Capital 24/I/1930.

${ }^{44}$ Los conscriptos y los actos de incultura. In: La Capital 24/I/1930.

${ }^{45}$ Los datos estadísticos han sido extraídos de la comunicación que la Empresa de Tranvías Eléctricos de Rosario envió al CD ante el conflicto suscitado por la posible municipalización del servicio que finalmente fue operada al año siguiente. 31/VII/1931 Comunicación de la Empresa de Tranvías Eléctricos de Rosario al CD, repasando su trayectoria en la ciudad. In: ET HCD Conflicto Tranviario 1932, f. 11.

${ }^{46}$ Los tranvías en la ciudad. Manifestaciones de Incultura. In: La Capital 12/I/1923.

${ }^{47}$ Stuart Hall ha indicado que los códigos de codificación y decodificación no siempre son simétricos. Aunque, la recodificación que la prensa 
produce sobre esos códigos de interacción en la relación cultura e incultura los represente así. Cf. HALL, Stuart Encouding/decouding. In: Culture, media y language. London: Hutchinson, 1980, pp. 129-139.

${ }^{48}$ ET HCD noviembre 1922, t. 1, ff. 201-203 y 234; ET HCD noviembre 1923, ff. 90 y 319-369.

49 11/X/1925 Ordenanza de circulación de ómnibus. In: ET HCD noviembre 1927, t. II, f. 3043.

${ }^{50}$ Ómnibus, Itinerarios y Tarifas. In: ET HCD septiembre 1929, t. II, f. 3043.

${ }^{51}$ Manifestaciones de incultura. In: La capital 5/I/1929.

52 FALCÓN, Ricardo La Barcelona Argentina. Migrantes, obreros y militantes en Rosario 1870-1912. Rosario: E. Laborde, 2005.

${ }^{53}$ La Capital 19/VIII/1932.

54 Según la nota consignada en La edad peligrosa. [In: La Capital 05/XII/1934.] fueron golpeados miembros del pasaje y un guardar recibió heridas de consideración.

55 ROLDÁN, Diego P. Del ocio a la fábrica..., cit., esp. pp. 205-281 y Chimeneas de Carne. Una historia del frigorífico Swift de Rosario 1907-1943. Rosario: Prohistoria Ediciones, 2008.

56 El problema del transporte a Saladillo. El directorio proyecta la instalación de vías por la calle Sarmiento hasta el frigorífico. In: Boletín Informativo de la Empresa Municipal Mixta de Transporte, v.2, n.26, abril, 1934.

57 Sobre los encuentros como los aquí descriptos como rituales ver: GOFFMAN, Erving Interation ritual. Essays on Face to Face Behavior. New York: Anchor Book, 1967.

${ }^{58}$ FOUCAULT, Michel Defender la sociedad. Curso en el Collège de France (1975-1976). México: Fondo de Cultura Económica, 2002

59 BALANDIER, Georges El desorden. La teoría del caos y las ciencias sociales. Barcelona: Gedisa, 1994.

${ }^{60}$ Sobre el concepto de aura ver: BENJAMIN, Walter La obra de arte en la época de su reproductibilidad técnica. In: Discursos Interrumpidos $I$. Madrid: Taurus, 1989, p. 26.

61 Sobre el concepto de poder de nominación ver: BOURDIEU, Pierre Espíritus de estado. Génesis y estructura del campo burocrático. In: Razones prácticas. Sobre la teoría de la acción. Barcelona: Anagrama, 1997, pp. 91-138.

${ }^{62}$ DE CERTEAU, Michel La invención de lo cotidiano. 1 Artes de Hacer. México: Universidad Iberoamericana, 1995.

${ }^{63}$ MONSIVAIS, Carlos Los rituales del caos. México: Editorial Era, 1995.

Artigo recebido em 08/2009. Aprovado em 11/2009. 